\title{
Ontogenic aspects of $D_{1}$ receptor coupling to $G$ proteins and regulation of rat jejunal $\mathrm{Na}^{+}, \mathrm{K}^{+}$ATPase activity and electrolyte transport
}

\author{
${ }^{1}$ M.A. Vieira-Coelho \& *,1 P. Soares-da-Silva \\ ${ }^{1}$ Institute of Pharmacology and Therapeutics, Faculty of Medicine, 4200 Porto, Portugal
}

1 The present study examined the effect of dopamine on rat jejunal electrolyte transport (rheogenic transport and $\mathrm{Na}^{+}, \mathrm{K}^{+}$-ATPase activity) in adult (60-day old) and young (20-day old) animals.

2 In young rats, dopamine, in the presence of phentolamine, produced an increase in jejunal $\mathrm{I}_{\mathrm{sc}}$, this being completely abolished by SKF 83566, and not changed by S-sulpiride. SKF 38393, but not quinerolane, also increased $I_{s c}$; this effect was abolished by SKF 83566 and ouabain, but not by furosemide. In adult rats, dopamine in the presence of phentolamine $(0.2 \mu \mathrm{M})$ decreased $\mathrm{I}_{\mathrm{sc}}$.

$3 \mathrm{Na}^{+}, \mathrm{K}^{+}$-ATPase activity in isolated jejunal epithelial cells from adult rats was 2.4 fold that in young rats. In the presence of phentolamine, both dopamine and SKF 38393, but not quinerolane, significantly decreased jejunal $\mathrm{Na}^{+}, \mathrm{K}^{+}$-ATPase activity in young animals but not in adult animals. 4 Binding $\left[{ }^{3} \mathrm{H}\right]-\mathrm{Sch} 23390$ to membranes of jejunal mucosa revealed the presence of a single class of receptors in both young and adult rats, with similar $\mathrm{K}_{\mathrm{D}}$ and $\mathrm{B}_{\max }$ values.

5 GTP $\gamma \mathrm{S}$ and cholera toxin inhibited jejunal $\mathrm{Na}^{+}, \mathrm{K}^{+}$-ATPase activity in young, but not in adult rats. Co-incubation of pertussis toxin with dopamine was found to potentiate the inhibitory effects of dopamine upon the enzyme in both young and adult rats.

6 Regulation of $\mathrm{Na}^{+}, \mathrm{K}^{+}$-ATPase activity by cholera toxin-sensitive $\mathrm{G}$ proteins is absent in adult animals, and such difference may explain the failure of dopamine to inhibit intestinal $\mathrm{Na}^{+}, \mathrm{K}^{+}$ATPase activity in adult rats.

British Journal of Pharmacology (2000) 129, 573-581

Keywords: G-proteins; dopamine; $\mathrm{D}_{1}$ receptors; jejunum; electrolyte transport; $\mathrm{Na}^{+}, \mathrm{K}^{+}$-ATPase

Abbreviations: AADC, aromatic L-amino acid decarboxylase; CTX, cholera toxin; DOPAC, 3,4-dihydroxyphenylacetic acid; GDP $\beta \mathrm{S}$, guanosine 5'-o-(2-thiodiphosphate); GTP $\gamma \mathrm{S}$, guanosine 5'-o-(3-thiotriphosphate); HVA, homovanillic acid; L-DOPA, 3,4-dihydroxyphenylalanine; 3-MT, 3-methoxytyramine; PDBu, phorbol 12,13-dibutyrate; PKA, protein kinase A; PKC, protein kinase C; PMA, phorbol 12-myristate 13-acetate; PMSF, Phenylmethyfsulphonyl fluoride; PTX, pertussis toxin

\section{Introduction}

The intestinal tract has been shown to be of crucial importance in the regulation of body fluid and electrolyte homeostasis with particular relevance in the control of changes in body fluid and electrolyte intake (Binder, 1983). Previous studies on neurohumoral control of intestinal transport showed that catecholamines stimulate electrolyte absorption. In the rat, dopamine was also found to stimulate ileal and colonic fluid absorption via dopamine and $\alpha_{2}$-adrenoceptors (Donowitz et al., 1983). More recently, it has been suggested that the $\alpha_{2}$ adrenoceptors involved in the pro-absorptive or antisecretory actions in the rat intestinal epithelium are of the $\alpha_{2 \mathrm{D}}$ or $\alpha_{2 \mathrm{~A}}$-like subtype (Liu \& Coupar, 1997). In contrast with this proabsorptive or antisecretory profile of dopamine, other studies showed that endogenous dopamine reduces jejunal sodium transport in young rats submitted to a high salt diet (Finkel et al., 1994), this being accomplished by a decrease in $\mathrm{Na}^{+}, \mathrm{K}^{+}$ATPase activity (Vieira-Coelho et al., 1998).

The current view of the intestinal dopaminergic system is that of a local non-neuronal system constituted by epithelial cells of intestinal mucosa, rich in aromatic L-amino acid decarboxylase (AADC) activity and using circulating or luminal 3,4-dihydroxyphenylalanine (L-DOPA) as a source for dopamine (Vieira-Coelho et al., 1997). Dopamine is particularly abundant in the mucosal cell layer (Eaker et al., 1988; Esplugues et al., 1985). Studies on the formation of

*Author for correspondence; E-mail: patricio.soares@mail.telepac.pt dopamine from exogenous L-DOPA along the rat digestive tract showed that the highest AADC activity is located in the jejunum (Vieira-Coelho \& Soares-da-Silva, 1993). Because the dopamine produced in this area is in close proximity to epithelial cells which contain receptors for the amine, it has been hypothesized that intestinal dopamine may act as a paracrine or autocrine substance (Vieira-Coelho et al., 1997). A high salt diet has been found to constitute an important stimulus for the production of dopamine in rat jejunal epithelial cells and this is accompanied, in 20-day old animals, by a decrease in sodium intestinal absorption (Finkel et al., 1994). The relative importance of this system in controlling sodium absorption assumes particular relevance in view of the findings that 40-day old rats submitted to a high salt diet have a fault in intestinal dopamine production during salt loading, in contrast to that occurring in 20-day old animals. The lack of changes in the jejunal function in response to high-salt diet coincides with the period in which the renal function has reached maturation (Robillard et al., 1992), suggesting the occurrence of complementary functions between the intestine and the kidney during development.

The present study was aimed to characterize the effect of dopamine on rat jejunal electrolyte transport (rheogenic transport and $\mathrm{Na}^{+}, \mathrm{K}^{+}$-ATPase activity) in young (20-day old) and adult (60-day old) rats and to determine the type of dopamine receptor involved. It is reported that, in the presence of $\alpha$-adrenoceptor blockade, dopamine produces a decrease in 
young rat jejunal electrolyte absorption. This effect, most probably due to inhibition of $\mathrm{Na}^{+}, \mathrm{K}^{+}$-ATPase, is a $\mathrm{D}_{1}$ receptor-mediated event, being absent in adult rats. The results presented here also indicate that intestinal $\mathrm{Na}^{+}, \mathrm{K}^{+}$-ATPase activity in young rats is regulated by both cholera toxin (CTX) and pertussis toxin (PTX) sensitive G proteins, but regulation of the enzyme by CTX-sensitive $G$ proteins is absent in adult animals. Such difference may explain the failure of dopamine to inhibit intestinal $\mathrm{Na}^{+}, \mathrm{K}^{+}$-ATPase activity in adult rats.

\section{Methods}

\section{Tissue preparation}

Adults (60-day old) male Wistar rats were fed a standard rat chow (Letica I.P.M R20) and received tap water ad libitum, whereas young (18-20-day old) rats were kept with the female progenitor for breast-feeding. Rats were killed by decapitation under ether anaesthesia and two segments of jejunum located $10-15 \mathrm{~cm}$ distal from the pyloric sphincter were removed. Each segment ( $2 \mathrm{~cm} \mathrm{long})$ of jejunum was cut longitudinally along the mesenteric border, washed free of luminal contents and the tissue pinned mucosal side down on a dental wax block. The serosa and muscularis were stripped away by dissection to obtain the epithelial sheets, as previously described (Nellans et al., 1974).

\section{Electrophysiological studies}

Epithelial sheets were mounted in Ussing chambers (window area $0.28 \mathrm{~cm}^{2}$ ) equipped with water-jacketed gas lifts, bathed on both sides with $10 \mathrm{ml}$ of Krebs-Hensleit solution, gassed with $95 \% \quad \mathrm{O}_{2}$ and $5 \% \quad \mathrm{CO}_{2}$ and maintained at $37^{\circ} \mathrm{C}$. DGlucose $(10 \mathrm{mM})$ was added to the serosal-side reservoir and an equimolar amount of mannitol to the mucosal-side reservoir. The Krebs-Hensleit solution contained (in $\mathrm{mM}$ ): $\mathrm{NaCl} 118, \mathrm{KCl} 4.7, \mathrm{NaHCO}_{3} 25, \mathrm{KH}_{2} \mathrm{PO}_{4} 1.2, \mathrm{CaCl}_{2} 2.5$, $\mathrm{MgSO}_{4} 1.2 ; \mathrm{pH}$ was adjusted to 7.4 after gassing with $5 \%$

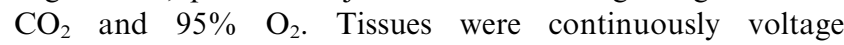
clamped to zero potential differences by application of external current, with compensation for fluid resistance, by means of an automatic voltage current clamp (DVC 1000, World Precision Instruments, Sarasota, Florida, U.S.A.). Transepithelial resistance $\left(\Omega \mathrm{cm}^{2}\right)$ was determined by altering the membrane potential stepwise $( \pm 5 \mathrm{mV})$ and applying the Ohmic relationship. Changes in short circuit current $(\mu \mathrm{A}$ $\mathrm{cm}^{-2}$ ) were continuously measured as an index of electrogenic ion transfer. The voltage/current clamp unit was connected to a PC via a BIOPAC MP1000 data acquisition system (BIOPAC Systems, Inc., Goleta, CA, U.S.A.). Data analysis was performed using AcqKnowledge 2.0 software (BIOPAC Systems, Inc., Goleta, CA, U.S.A.).

After a 30-45-min preincubation period, by which time the potential difference had stabilized, dopamine or SKF 38393, a selective dopamine $\mathrm{D}_{1}$ receptor selective agonist, was added to the serosal-side reservoir; ascorbic acid $(1 \mathrm{mM})$ was present in the serosal bathing solution to reduce oxidation of dopamine. All agonist concentrationresponse curves were constructed in a cumulative manner; each new concentration was added as soon as the potential difference response to the prior concentration reached its nadir. Antagonists were added 20 min before construction of an agonist concentration-response curve. All drugs were added to the serosal side.

\section{Isolation of jejunal epithelial cells}

The method of cell isolation was similar to that previously described (Kimmich, 1990; Quaroni et al., 1979) with minor modifications. Briefly, the animals were killed by decapitation under anaesthesia and the abdominal cavity was immediately opened to excise a jejunal segment approximately $10 \mathrm{~cm}$ in length. The selected segment was placed on an ice cold glass plate and cut in smaller segments of approximately $1.5 \mathrm{~cm}$ in length, and rinsed free from blood and intestinal contents with saline $(0.9 \% \mathrm{NaCl})$. The tissue fragments were everted with fine forceps and incubated for $45 \mathrm{~min}$ in $5 \mathrm{ml}$ warm water $\left(37^{\circ} \mathrm{C}\right)$ and gassed $\left(95 \% \mathrm{O}_{2}\right.$ and $\left.5 \% \mathrm{CO}_{2}\right)$ Hanks' solution with $0.06 \%$ collagenase type I (Sigma Chemical Co, St Louis, MO, U.S.A.). At the end of the incubation period the fragments were removed from the solution and the medium containing the detached cells was centrifuged $\left(200 \times g, 4^{\circ} \mathrm{C}\right)$ for $4 \mathrm{~min}$, and the cell pellet was re-suspended in Hanks' solution. Cell viability was estimated by the Trypan blue $(0.04 \% ; 1 \mathrm{~min})$ exclusion method, and the percentage of viable cells (excluding the dye), determined by hemocytometer counting, was $>90 \%$.

\section{Membrane preparations and $D_{1}$ binding assay}

Membranes from intestinal mucosa were obtained from adult and young male Wistar rats. After ether anaesthesia, a segment of jejunum $(5-10 \mathrm{~cm})$ was removed, opened longitudinally along the mesenteric border and rinsed free from the alimentary content with cold saline $(0.9 \% \mathrm{NaCl})$ and the jejunal mucosa was removed with a scalpel. The mucosa thus obtained was homogenized in (mM): Tris- $\mathrm{HCl} 10, \mathrm{pH} 7.4$, containing sucrose 250, PMSF 1, EDTA 1 , and $5 \mu \mathrm{g} \mathrm{m}^{-1}$ each of leupeptin and pepstatine, with a Potter-Elvehjem teflon homogenizer, and centrifuged $\left(20,000 \times g, 20 \mathrm{~min}, 4^{\circ} \mathrm{C}\right)$. Pellets were resuspended to a concentration of $2 \mathrm{mg}$ protein $\mathrm{ml}^{-1}$ in (mM) Tris- $\mathrm{HCl} \mathrm{10,}$ $\mathrm{pH} 7.4$ with $\mathrm{MgCl}_{2} 5$ and sucrose 250 and stored aliquoted at $-80^{\circ} \mathrm{C}$. Membranes were thawed at room temperature, centrifuged $\left(20,000 \times \mathrm{g}, 20 \mathrm{~min}, 4^{\circ} \mathrm{C}\right)$ and resuspended in binding buffer (mM): Tris- $\mathrm{HCl} 50, \mathrm{pH} 7.4$ with $\mathrm{NaCl} 120, \mathrm{KCl}$ 5, $\mathrm{CaCl}_{2} 2$ and $\mathrm{MgCl}_{2}$ 1. Saturation experiments were performed in four replicates in 96-well EIA/RIA plates (Costar) in a final volume of $0.2 \mathrm{ml}$ binding buffer containing $0.1-10 \mathrm{nM}\left[{ }^{3} \mathrm{H}\right]-\mathrm{Sch}$ 23390 and $100-200 \mu \mathrm{g}$ membrane protein. Non-specific binding was determined in the presence of $10 \mu \mathrm{M}$ of unlabelled Sch 23390 (Gil-Martín et al., 1997; Horiuchi et al., 1992). After 30 min incubation at $30^{\circ} \mathrm{C}$ in a shaking water bath, assays were terminated by vacuum filtration through glass fibre filtermats with the Brandel 96 cell Harvester (Brandel, Gaithsburg, U.S.A.). Filters were washed three times with $200 \mu$ l of cold $50 \mathrm{~mm}$ Tris-HCl pH 7.4, dried and impregnated with MeltiLex A (Wallac, Pharmacia) and DPM determined in a Microbeta counter (Wallac) with 20\% efficiency.

\section{$\mathrm{Na}^{+}, \mathrm{K}^{+}-$ATPase assay}

$\mathrm{Na}^{+}, \mathrm{K}^{+}$-ATPase activity was measured by the method of Quigley \& Gotterer (1969), with minor modifications. Briefly, epithelial cells were incubated with dopamine $(1 \mu \mathrm{M})$ or SKF $38393(10 \mathrm{nM})$, the selective $\mathrm{D}_{1}$ receptor agonist, for $15 \mathrm{~min}$ at $37^{\circ} \mathrm{C}$. In some experiments, incubation was performed in the presence of $\mathrm{D}_{1}$ or $\mathrm{D}_{2}$ selective antagonists, respectively SKF $83566(1 \mu \mathrm{M})$ and $\mathrm{S}$-sulpiride $(1 \mu \mathrm{M})$. In another set of experiments, cells were incubated in the presence of dibutyril cyclic AMP (2 mM), phorbol 12,13-dibutyrate (PDBu; $1 \mu \mathrm{M})$, phorbol 12-myristate 13-acetate (PMA; $1 \mu \mathrm{M})$, cyclic GMP (1 mM), guanosine 5'-o-(3-thiotriphosphate) (GTP $\gamma \mathrm{S} ; 50,100$ 
and $150 \mu \mathrm{M})$, guanosine 5'-o-(2-thiodiphosphate) (GDP $\beta \mathrm{S} ; 50$, 100 and $150 \mu \mathrm{M})$, cholera toxin (CTX; $0.1 \mu \mathrm{M})$ or pertussis toxin (PTX; $0.1 \mathrm{nM}$ ) for $30 \mathrm{~min}$ at $37^{\circ} \mathrm{C}$. After the incubation period the cells were permeabilized by rapid freezing in dry iceacetone and thawing. The reaction mixture contained (in $\mathrm{mM}$ ): imidazole buffer $37.5, \mathrm{NaCl} 75, \mathrm{KCl} 5$, sodium EDTA 1, $\mathrm{MgCl}_{2} \quad 5,6 \mathrm{NaN}_{3}$, tris(hydroxymethyl)aminomethane(tris) hydrochloride 75 and $100 \mu \mathrm{l}$ cell suspension (100 $\mu$ g protein). The reaction was initiated by the addition of $4 \mathrm{mM} \mathrm{ATP.} \mathrm{For}$ determination of ouabain-insensitive ATPase, $\mathrm{NaCl}$ and $\mathrm{KCl}$ were omitted, and ouabain $(1 \mathrm{~mm} ; 100 \mu \mathrm{l})$ or vehicle (water; $100 \mu \mathrm{l})$ were added to the assay. After incubation at $37^{\circ} \mathrm{C}$ for $15 \mathrm{~min}$, the reaction was terminated by the addition of $50 \mu \mathrm{l}$ of ice-cold trichloroacetic acid. Samples were centrifuged (3000 r.p.m.), and liberated $P_{i}$ in supernatant was measured by spectrophotometry at $740 \mathrm{~nm}$. Na ${ }^{+}, \mathrm{K}^{+}$-ATPase activity is expressed as nanomoles $\mathrm{P}_{\mathrm{i}}$ per milligram protein per minute and determined as the difference between total and ouabaininsensitive ATPase.

\section{Assay of catecholamines}

The assay of catecholamines and its metabolites in the jejunal mucosa (L-DOPA, noradrenaline, dopamine, 3,4-dihydroxyphenylacetic acid [DOPAC], 3-methoxytyramine [3-MT] and homovanillic acid [HVA]) was performed by h.p.l.c. with electrochemical detection, as previously described (Soares-daSilva et al., 1995). In brief, aliquots of $1.5 \mathrm{ml}$ of perchloric acid in which tissues had been kept were placed in $5 \mathrm{ml}$ conicalbased glass vials with $50 \mathrm{mg}$ alumina and the $\mathrm{pH}$ of the samples adjusted to $\mathrm{pH} 8.6$ by addition of Tris buffer. The adsorbed catecholamines were then eluted from the alumina with $200 \mu \mathrm{l}$ of $0.2 \mathrm{M}$ perchloric acid on Costar Spin-X microfilters; $50 \mu \mathrm{l}$ of the eluate was injected into a h.p.l.c. (Gilson Medical Electronics, Villiers le Bel, France). For the quantification of 3-MT and HVA in tissue samples, $500 \mu \mathrm{l}$ of perchloric acid in which tissues had been kept were filtered on Costar Spin-X microfilters and directly injected into the chromatograph. The lower limit of detection of L-DOPA, noradrenaline, dopamine, DOPAC, 3-MT and HVA ranged from 350 to 1000 fmol.

\section{Drugs}

The compounds used were: adenosine $3^{\prime}: 5^{\prime}$-cyclic monophosphate N6,2'-o-dibutyril (dibutyril cyclic AMP), cholera toxin, dopamine hydrochloride, forskolin, furosemide, guanosine $3^{\prime}: 5^{\prime}$-cyclic monophosphate sodium salt (cyclic GMP), guanosine 5'-o-(3-thiotriphosphate) (GTP $\gamma \mathrm{S})$, guanosine 5'-o-(2thiodiphosphate) (GDP $\beta S$ ), ouabain, phentolamine hydrochloride, phorbol 12,13-dibutyrate (PDBu) and phorbol 12myristate 13-acetate (PMA) obtained from Sigma Chemical Company (St. Louis, MO, U.S.A.). Quinerolane, Sch 23390, SKF 38393, SKF 83566 and (S)-sulpiride were obtained from Research Biochemicals International (RBI, Natick, MA, U.S.A.). $\quad\left[{ }^{3} \mathrm{H}\right]-\mathrm{Sch} \quad 23390 \quad$ ([N-methyl- $\left.{ }^{3} \mathrm{H}\right] \mathrm{R}[+]-7$-chloro2,3.4,5-tetrahydro - 3 - methyl - 1 - phenyl - $1 \mathrm{H}$ - 3benzazepine-8ol, specific activity $2600-3200 \mathrm{GBq} \mathrm{mmol}^{-1}$ was purchased from New England Nuclear (Boston, MA, U.S.A).

\section{Analysis of data}

Results are given as arithmetic means \pm s.e.mean. $\mathrm{EC}_{50}$ values and $\left[{ }^{3} \mathrm{H}\right]$-Sch 23390 saturation parameters, $B_{\max }$ and $\mathrm{K}_{\mathrm{D}}$, were calculated using GraphPad Prism software package (Motulsky et al., 1994). Statistical analysis were performed by one-way analysis of variance (ANOVA) followed by Newman-Keuls test for multiple comparisons or Student's $t$-test. A $P$ value less than 0.05 was assumed to denote a significant difference.

\section{Results}

\section{Electrophysiological studies}

Jejunal preparations from 20- and 60-day old rats exhibited a mean basal $\mathrm{I}_{\mathrm{sc}}$ value (in $\mu \mathrm{A} \mathrm{cm}^{-2}$ ) of $28.7 \pm 2.9$ and $23.1 \pm 2.4$ $(n=40)$, respectively. In 60 -day old rats, dopamine $(0.1-$ $100 \mu \mathrm{M})$ when applied alone from the basal side produced a concentration dependent decrease in $\mathrm{I}_{\mathrm{sc}}$ with a $\mathrm{EC}_{50}$ value of $1.0(0.4,2.6) \mu \mathrm{M}$. In 20-day old rats, under the some experimental conditions, dopamine $(0.1-100 \mu \mathrm{M})$ also produced a concentration dependent decrease in $\mathrm{I}_{\mathrm{sc}}$ with a $\mathrm{EC}_{50}$ value of $7.0(3.3,14.8) \mu \mathrm{M}$ (Figure 1). However, in the presence of phentolamine $(0.2 \mu \mathrm{M})$ a non-selective $\alpha$-adrenoceptor antagonist, the effect of dopamine in young animals was a biphasic effect (Figure 1A). At low concentrations (0.13.0 $\mu \mathrm{M})$, the effect of dopamine was a concentration dependent increase in $\mathrm{I}_{\mathrm{sc}}$ (maximal effect, $33.6 \pm 0.4 \%$ increase) with a $\mathrm{EC}_{50}$ value of $0.1(0.07,2.5) \mu \mathrm{M}$. At high concentrations (10$100 \mu \mathrm{M})$, the effect of dopamine was a concentration
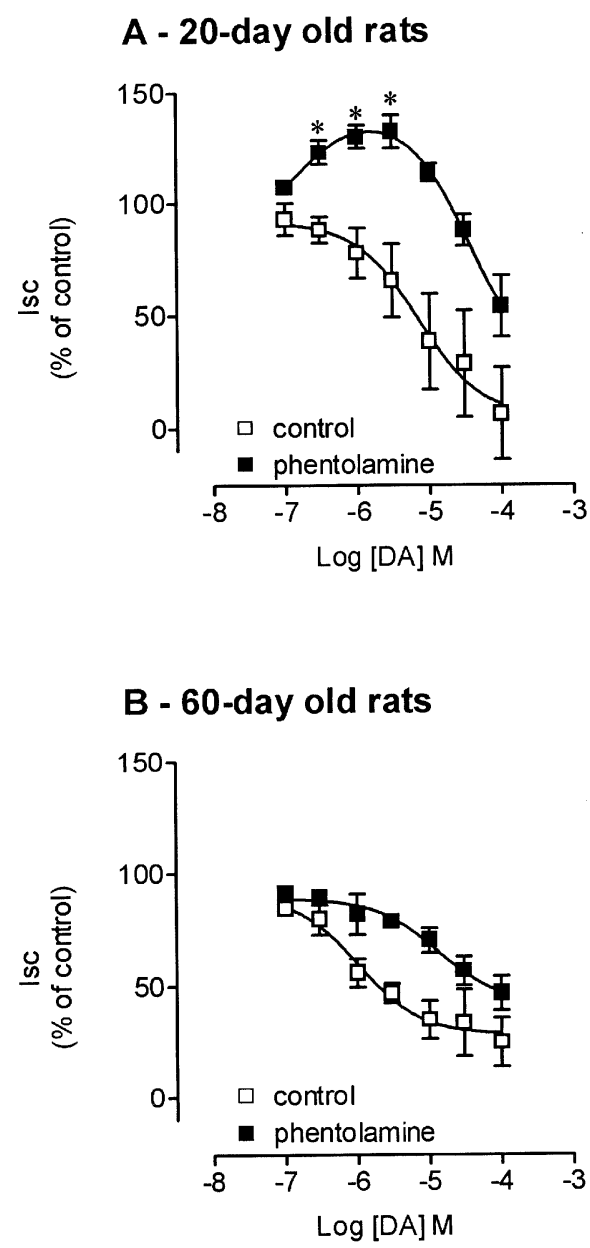

Figure 1 Concentration-response curves to dopamine (DA) in the absence $(\square)$ and the presence $(\square)$ of phentolamine $0.2 \mu \mathrm{M}$ on $\mathrm{I}_{\mathrm{sc}}$ in voltage-clamped rat jejunal epithelial sheets from (A) 20-day old and (B) 60-day old rats. Symbols represent means of four to five experiments per group; vertical lines show s.e.mean. ${ }^{*}$ Significantly different from baseline values $(P<0.05$; Newman-Keuls test). 
dependent decrease in $\mathrm{I}_{\mathrm{sc}}$ with a $\mathrm{EC}_{50}$ value of $35.5(14.9,84.5)$ $\mu \mathrm{M}$ (Figure 1A). By contrast, in adult animals the effect of dopamine $(0.1-100 \mu \mathrm{M})$ in the presence of phentolamine $(0.2 \mu \mathrm{M})$ was still a concentration dependent decrease in $\mathrm{I}_{\mathrm{sc}}$ and no increase was observed. In fact, in adult animals the addition of phentolamine $(0.2 \mu \mathrm{M})$ produced a rightward shift of the dopamine concentration-dependent curve with a significant increase in $\mathrm{EC}_{50}$ values up to $12.9(5.4,30.7) \mu \mathrm{M}$ (Figure 1B). In adult animals the effect of dopamine was completely abolished by $1 \mu \mathrm{M}$ phentolamine (data not shown).

The increase in $I_{\text {sc }}$ produced by low concentrations $(0.1-$ $3.0 \mu \mathrm{M})$ of dopamine in 20-day old rats was completely abolished by the selective $\mathrm{D}_{1}$ antagonist, SKF $83566(1 \mu \mathrm{M})$, but not by the selective $\mathrm{D}_{2}$ antagonist $\mathrm{S}$-sulpiride $(1 \mu \mathrm{M})$ (Figure 2A). The selective $D_{1}$ agonist SKF $38393(0.1-10 \mathrm{nM})$ applied from the basal side was also found to produce a concentration dependent increase in $\mathrm{I}_{\mathrm{sc}}$ (maximal effect, $30 \pm 6 \%$ increase) with a $\mathrm{EC}_{50}$ value of $0.31(0.23,0.43) \mathrm{nM}$, this being abolished by SKF $83566(1 \mu \mathrm{M})$. By contrast, jejunal $\mathrm{I}_{\mathrm{sc}}$ was not significantly affected by quinerolane $(0.1-100 \mathrm{nM})$, the selective $\mathrm{D}_{2}$ agonist, alone or in combination with S-sulpiride (data not shown). The increase in $\mathrm{I}_{\mathrm{sc}}$ produced by SKF $38393(0.1-10 \mathrm{nM})$ was completely abolished by ouabain $(1 \mathrm{~mm}) \mathrm{a} \mathrm{Na}^{+}, \mathrm{K}^{+}$-ATPase
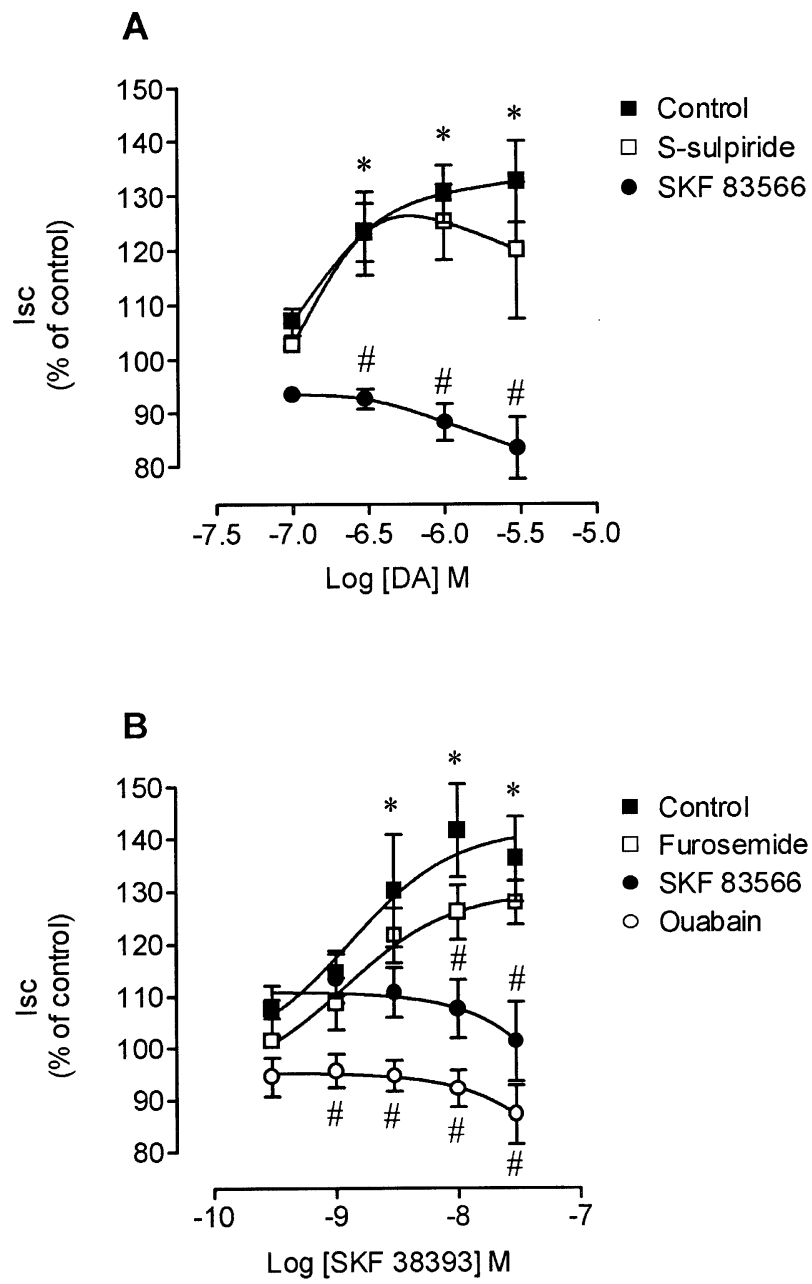

Figure 2 Concentration-response curves to (A) dopamine (DA) and (B) SKF 38393 on $I_{\text {sc }}$ in voltage-clamped jejunal epithelial sheets from 20-day old rats, in the absence and in the presence of $1 \mu \mathrm{M} \mathrm{SKF}$ $83566,1 \mathrm{~mm}$ ouabain or $1 \mathrm{~mm}$ furosemide. Symbols represent means of four to five experiments per group; vertical lines show s.e.mean. Significantly different from baseline values $(* P<0.05$; Newman-Keuls test) and corresponding control values (\#P<0.05; Newman-Keuls test). pump inhibitor, whereas furosemide (1 mM), a blocker of the $\mathrm{Na}^{+}-\mathrm{K}^{+}-2 \mathrm{Cl}^{-}$transporter, failed to alter the response to $\mathrm{D}_{1}$ receptor stimulation (Figure 2).

\section{$\left[^{3} \mathrm{H}\right]-S c h 23390$ binding assay}

To explore differences in the density of dopamine receptors that might explain the absence of $\mathrm{D}_{1}$ receptor-mediated responses in adult animals, radioligand-binding experiments with $\left[{ }^{3} \mathrm{H}\right]-\mathrm{Sch}$ $23390(0.1-10 \mathrm{nM})$ were performed in membranes prepared from young and adult rat intestinal mucosa. Non-linear analysis of saturation experiments with $\left[{ }^{3} \mathrm{H}\right]-\mathrm{Sch} 23390$ (Figure 3) revealed the presence of a single class of receptors in both young and adult rats, with no significant differences in $\mathrm{K}_{\mathrm{D}}$ values (young $=3.4 \mathrm{nM}[0.3 ; 6.5]$; adult $=7.5 \mathrm{~nm}[3.8 ; 11.2])$. The maximal density of $\mathrm{D}_{1}$ binding sites (in fmol $\mathrm{mg}_{\text {protein }}{ }^{-1}$ ) in adult animals $(539.3 \pm 64.9)$ was even greater than in young rats $(315.8 \pm 49.3)$. The kinetic parameters of the $\mathrm{D}_{1}$ binding site reported here for adult rats differ from those described in the literature (Marmon et al., 1993). $\mathrm{K}_{\mathrm{D}}$ values are in the same range of magnitude, but $\mathrm{B}_{\max }$ values were found to be markedly higher

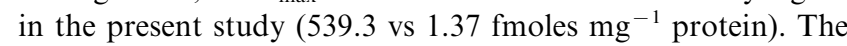
most likely explanation for this apparent discrepancy is concerned with the fact that these authors used the entire intestinal wall, whereas we used the intestinal mucosa only. This may suggest that $D_{1}$ receptors would be preferentially located in the mucosal cells and not homogeneously distributed across the intestinal wall, which is in agreement with data obtained in autoradiography studies showing that $\mathrm{D}_{1}$ binding sites are localised primarily in the mucosal cells in the base of the crypts.

\section{$\mathrm{Na}^{+}, \mathrm{K}^{+}$-ATPase activity}

Because the effects of dopamine upon $\mathrm{I}_{\mathrm{sc}}$ in young rats were sensitive to ouabain and antiabsorptive in nature (furosemide insensitive increases in $\mathrm{I}_{\mathrm{sc}}$ ), it was decided to evaluate $\mathrm{Na}^{+}, \mathrm{K}^{+}$ATPase activity in isolated jejunal epithelial cells. $\mathrm{Na}^{+}, \mathrm{K}^{+}$ATPase activity (in nmol Pi mg protein ${ }^{-1} \mathrm{~min}^{-1}$ ) in adult rats $(123 \pm 3)$ was found to be 2.4 fold higher than in young rats $(52 \pm 4)$ (Figure 4). Both dopamine $(1 \mu \mathrm{M}$; with added $0.2 \mu \mathrm{M}$ phentolamine) and SKF $38393(10 \mathrm{nM})$, but not quinerolane $(10 \mathrm{nM})$, significantly $(P<0.05)$ decreased jejunal $\mathrm{Na}^{+}, \mathrm{K}^{+}$-

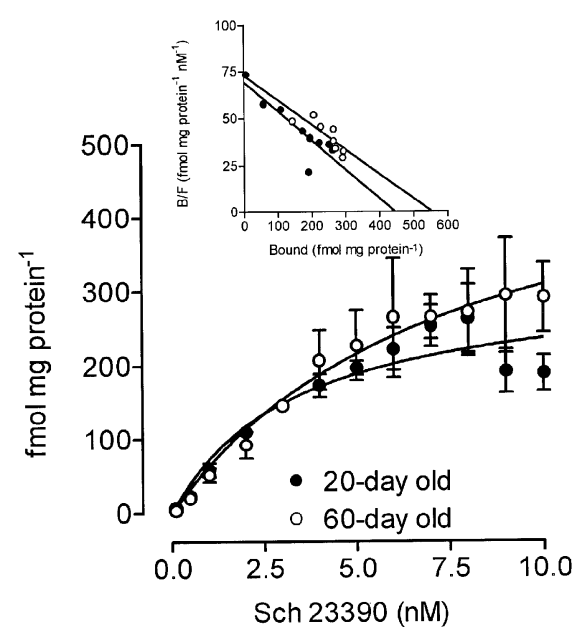

Figure 3 Saturation curves of $\left[{ }^{3} \mathrm{H}\right]-\mathrm{Sch} 23390$ specific binding to rat jejunal mucosal membranes obtained from $20-(\bigcirc)$ and $60-(\bigcirc)$ day old rats. The inset shows the respective representative Scatchard plot. Non-specific binding was determined in the presence of unlabelled $10 \mu \mathrm{M}$ SCH 23390. Each symbol represents the mean of four experiments performed in quadruplicate; vertical lines show s.e.mean. 
ATPase activity in young animals (Figure 4). By contrast, in adult animals dopamine $(1 \mu \mathrm{M}$; with added $0.2 \mu \mathrm{M}$ phentolamine), SKF $38393(10 \mathrm{nM})$ and quinerolane $(10 \mathrm{nM})$ failed to inhibit jejunal $\mathrm{Na}^{+}, \mathrm{K}^{+}$-ATPase (Figure 4). In agreement with the results from electrophysiological data, the inhibitory effect of dopamine $(1 \mu \mathrm{M})$ in jejunal $\mathrm{Na}^{+}, \mathrm{K}^{+}$-ATPase activity from young animals was completely abolished by SKF 83566 (1 $\mu \mathrm{M})$, but not by S-sulpiride $(1 \mu \mathrm{M})$ (Figure 4$)$.

Second messenger pathways thought to be involved in $D_{1}$ receptor-mediated events include stimulation of protein kinase A (PKA) or C (PKC) pathways (Jose et al., 1992). To examine the hypothesis whether failure to respond to dopamine with inhibition of $\mathrm{Na}^{+}, \mathrm{K}^{+}$-ATPase activity was related or not to lack of responsiveness to stimulation of PKA or PKC, it was decided to evaluate the effect of stimuli leading activation of these pathways. As shown in Figure 5, both dibutyril cyclic AMP and forskolin were effective in reducing basal jejunal $\mathrm{Na}^{+}, \mathrm{K}^{+}$-ATPase activity. Similarly, PKC activation with $\mathrm{PDBu}$ and PMA was accompanied with inhibition of $\mathrm{Na}^{+}, \mathrm{K}^{+}$-ATPase activity. By contrast, cyclic GMP failed to alter $\mathrm{Na}^{+}, \mathrm{K}^{+}$-ATPase activity. Altogether, these results suggest that $\mathrm{Na}^{+}, \mathrm{K}^{+}$-ATPase in jejunal epithelial cells from adult rats respond with inhibition to stimuli usually involved in $D_{1}$ receptor-mediated events.

At this stage it was considered important to evaluate the involvement of $\mathrm{G}$ proteins in the regulation of $\mathrm{Na}^{+}, \mathrm{K}^{+}$-ATPase in epithelial intestinal cells from young and adult rats. To demonstrate that $G$ proteins were involved in the regulation of intestinal $\mathrm{Na}^{+}, \mathrm{K}^{+}$-ATPase, isolated epithelial cells were

\section{A - 20-day old rats}

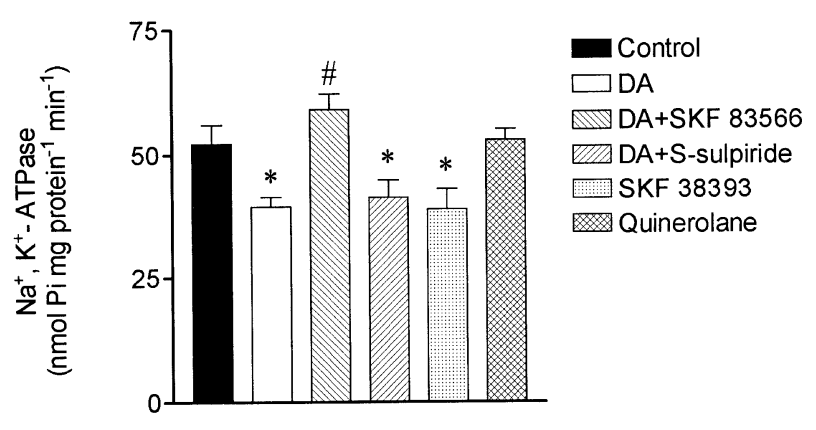

\section{B - 60-day old rats}

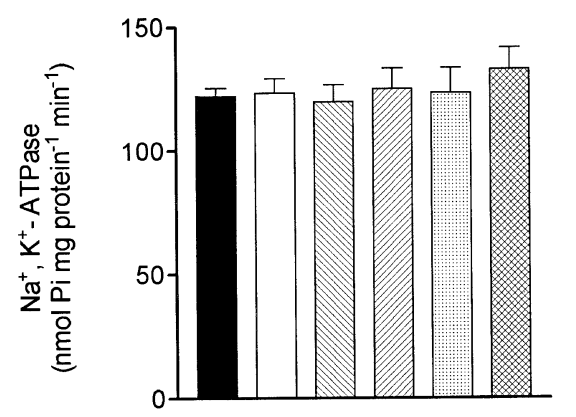

Figure $4 \mathrm{NA}^{+}, \mathrm{K}^{+}$-ATPase activity in isolated jejunal epithelial cells from (A) 20- and (B) 60-day old rats in the absence (control) and the presence of $1 \mu \mathrm{M}$ dopamine (DA) alone, $1 \mu \mathrm{M}$ DA plus $10 \mathrm{nM}$ SKF 83566, $1 \mu \mathrm{M}$ DA plus $1 \mu \mathrm{M}$ S-sulpiride, $10 \mathrm{~nm}$ SKF 38393 and $10 \mathrm{~nm}$ quinerolane. Columns represent means of four to five experiments per group; vertical lines show s.e.mean. Significantly different from corresponding control values $(* P<0.05$; NewmanKeuls test) and values for dopamine alone (\#P<0.05; NewmanKeuls test). incubated in the presence of $\operatorname{GTP} \gamma \mathrm{S}(15,50$ and $150 \mu \mathrm{M})$, a nonhydrolyzable analogue of GTP, that irreversibly activates G proteins (Gurich \& Beach, 1994). This resulted in a concentration dependent inhibition of intestinal $\mathrm{Na}^{+}, \mathrm{K}^{+}$-ATPase activity in young animals (Figure 6A), with no significant effect in adult animals (Figure 6B). The compound GDP $\beta$ S, an analogue of GTP that does not activate $G$ proteins (Gurich \& Beach, 1994), had no affect on intestinal $\mathrm{Na}^{+}, \mathrm{K}^{+}$-ATPase in both young and adult animals (Figure 6). These results demonstrate that nonspecific activation of $G$ proteins can regulate intestinal $\mathrm{Na}^{+}, \mathrm{K}^{+}$-ATPase in young, but not adult rats.

Since GTP $\gamma$ S activates all classes of $G$ proteins, the effects of cholera toxin and pertussis toxin that ribosylates the $\alpha$-subunit of the Gs and Gi/o classes of $\mathrm{G}$ proteins, respectively, were also evaluated. Cholera toxin $0.1 \mu \mathrm{M}$ inhibited $\mathrm{Na}^{+}, \mathrm{K}^{+}$-ATPase activity by $23.6 \pm 4.4 \%$ in young rats, but had no effect in adult rats (Figure 7). In both young and adult animals, pretreatment of intestinal cells with pertussis toxin $0.1 \mathrm{nM}$ failed to affect $\mathrm{Na}^{+}, \mathrm{K}^{+}$-ATPase activity. However, co-incubation of PTX with dopamine was found to potentiate the inhibitory effects of dopamine $(1 \mu \mathrm{M})$ upon $\mathrm{Na}^{+}, \mathrm{K}^{+}$-ATPase in young rats $(40.4 \pm 5.8 \%$ reduction). In adult animals, although dopamine $1 \mu \mathrm{M}$ alone failed to inhibit intestinal sodium pump activity, the addition of PTX $(0.1 \mathrm{nM})$ plus dopamine $(1 \mu \mathrm{M})$ resulted in a significant $(P<0.05)$ inhibition of $\mathrm{Na}^{+}, \mathrm{K}^{+}$-ATPase activity $(15.2 \pm 3.9 \%$ reduction $)$.

Table 1, indicates the levels of L-DOPA, noradrenaline, dopamine and amine metabolites in the jejunal mucosa of young and adult rats. As can be observed in the table, levels of dopamine were more than twice in young rats compared to the adult animals, whereas levels of noradrenaline were less than half in the former. This resulted in that dopamine/noradrenaline tissue ratios in young animals were 7.5 fold those in adult animals.

\section{Discussion}

The results presented here clearly show that the effects of dopamine on jejunal electrolyte (rheogenic) transport and on $\mathrm{Na}^{+}, \mathrm{K}^{+}$-ATPase activity in young rats differs markedly from those observed in adult animals. In young animals the effects of dopamine are mediated through the activation of $D_{1}$ receptors and these occur predominantly at low concentrations of the amine, resulting in inhibition of $\mathrm{Na}^{+}, \mathrm{K}^{+}$-ATPase

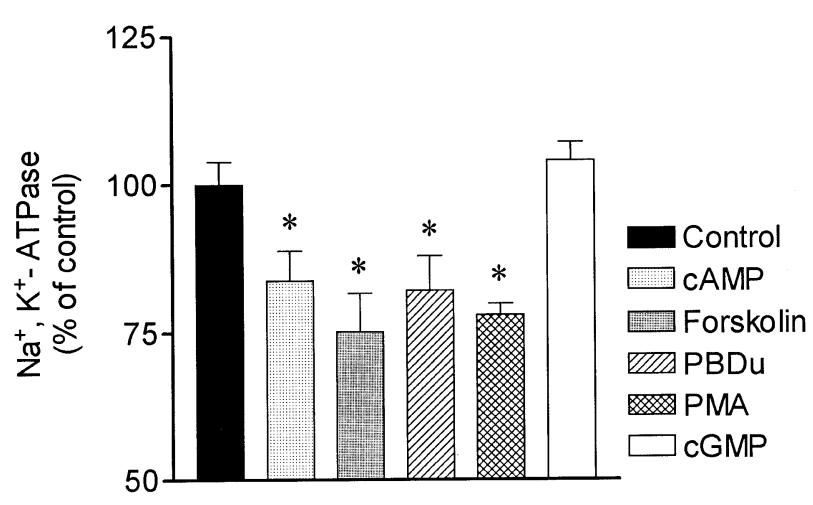

Figure 5 Effects of dibutyryl-cyclic AMP (2 mM), forskolin $(10 \mu \mathrm{M})$, PDBu $(1 \mu \mathrm{M})$, PMA $(1 \mu \mathrm{M})$ and cyclic GMP (1 mM) upon jejunal $\mathrm{NA}^{+}, \mathrm{K}^{+}$-ATPase activity in 60 -day old rats. Columns represent means of four experiments per group; vertical lines show s.e.mean. *Significantly different from corresponding control values $(P<0.05$; Newman-Keuls test). 
activity. Jejunal $\mathrm{Na}^{+}, \mathrm{K}^{+}$-ATPase activity in young rats is regulated by both CTX- and PTX-sensitive G proteins, but regulation of the enzyme by CTX-sensitive $\mathrm{G}$ proteins is absent in adult animals. Such difference may explain the failure of dopamine to inhibit intestinal $\mathrm{Na}^{+}, \mathrm{K}^{+}$-ATPase activity in adult rats. However, jejunal $\mathrm{Na}^{+}, \mathrm{K}^{+}$-ATPase in adult rats appears to be an effector protein of both PKA and PKC, as stimulation of PKA- and PKC-mediated pathways (usually involved in $\mathrm{D}_{1}$ receptor activation) produce marked inhibition of sodium pump activity.

In the absence of phentolamine, when $\alpha$-adrenoceptors operate, the main effect of dopamine was a decrease in $I_{s c}$ in jejunal sheets from both young and adult rats. This was particularly evident at high concentrations of the amine and indicates that at this level of agonist concentration the predominant effects are those mediated by $\alpha$-adrenoceptors and not through the activation of receptors specific for the amine, which is in agreement with data in the literature (Goldberg \& Rajfer, 1985). Because levels of endogenous dopamine in the jejunal mucosa are relatively low, it is unlikely the main effects of dopamine would be promoted through activation of $\alpha$-adrenoceptors. In adult rats, despite effective $\alpha$ adrenoceptor blockade with phentolamine the effect of dopamine is still a decrease in $I_{\mathrm{sc}}$. This is in agreement with previous work performed in adult rats showing that the effects of dopamine on jejunal $I_{\mathrm{sc}}$ are mediated by $\alpha_{2}$-adrenoceptors

\section{A - 20-day old rats}

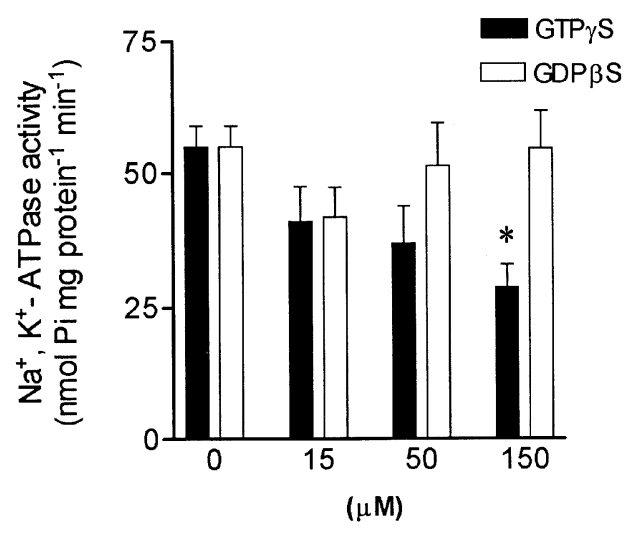

B - 60-day old rats

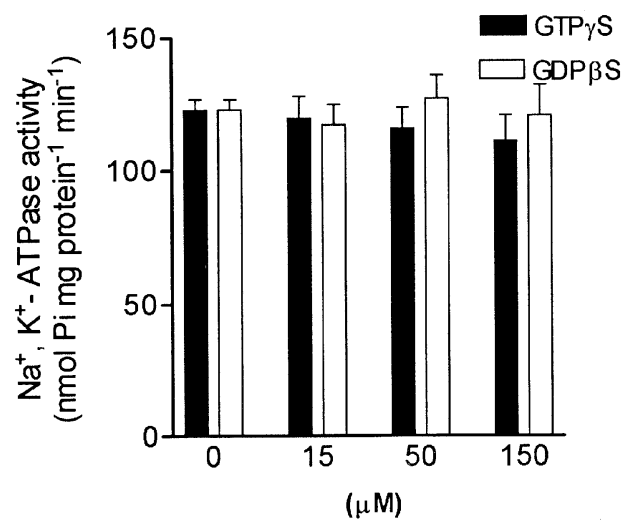

Figure 6 Effects of guanosine 5'-O-(3-thiotriphosphate) (GTP $\gamma \mathrm{S})$ and guanosine $5^{\prime}$-o-(2-thiodiphosphate) (GDP $\left.\beta \mathrm{S}\right)$, on intestinal $\mathrm{Na}^{+}$, $\mathrm{K}^{+}$-ATPase activity from (A) 20- and (B) 60-day old rats. Columns represent means of four to five experiments per group; vertical lines show s.e.mean. *Significantly different from corresponding control values $(P<0.05$; Newman-Keuls test $)$.
(Vieira-Coelho \& Soares-da-Silva, 1998). On the other hand, in young rats, when phentolamine is present, the effect of dopamine is a biphasic one. At low concentrations (0.1$3.0 \mu \mathrm{M})$, dopamine increases $\mathrm{I}_{\mathrm{sc}}\left(\mathrm{EC}_{50}=0.1 \mu \mathrm{M}\right)$, whereas at higher concentrations $(10-100 \mu \mathrm{M})$ the effect of dopamine is an opposite one, resulting in a concentration-dependent decrease in $\mathrm{I}_{\mathrm{sc}}\left(\mathrm{EC}_{50}=35.5 \mu \mathrm{M}\right)$. The finding that this increase in $I_{s c}$ by low concentrations of dopamine was completely abolished by selective $D_{1}$, but not by selective $D_{2}$, receptor blockade, strongly suggests that these effects are mediated through the activation of specific dopamine receptors of the $D_{1}$ subtype. It is interesting, however, to observe that the rightward shift of the concentration-response curve for dopamine in the absence and the presence of phentolamine in adult rats ( 12 fold) is greater than that observed in young rats ( 8 fold). This may indicate that the sensitivity of the $\alpha$ adrenoceptors to dopamine in adult rats is greater than that in young animals, which is in agreement with the marked difference in $\mathrm{EC}_{50}$ values for dopamine (in the absence of phentolamine) between young $(7.0(3.3,14.8) \mu \mathrm{M})$ and adult $(1.0(0.4,2.6) \mu \mathrm{M})$ rats. Thus, it might be concluded that in the jejunum of 20-day old rats the $\alpha$-adrenergic response to dopamine are not easy to arouse. The reason for this to occur can not be attributed exclusively to the presence in young rats of an antagonistic dopaminergic component, but it is possible that this may contribute for the observed response to the amine. Another possible explanation may be that adult animals are endowed with a density of $\alpha$-adrenoceptors greater than that in young rats. To our knowledge there is no indication in the literature that this is the case for the rat jejunum. However, the ontogeny of $\alpha$-adrenoceptors has been quite well defined in other tissues and the overall view fits well the suggestion of a age dependent receptor density (Gitler et

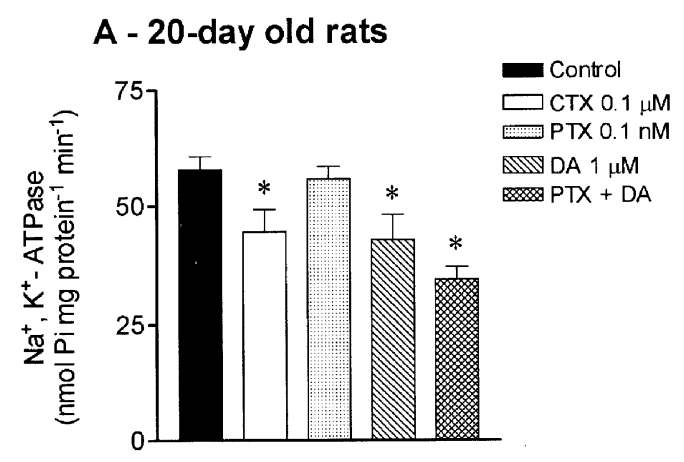

\section{B - 60-day old rats}

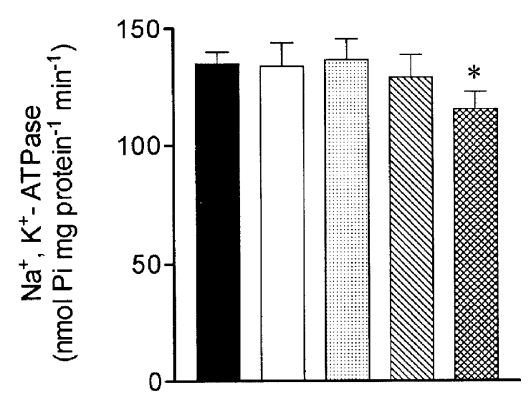

Figure 7 Effects of cholera toxin (CTX; $0.1 \mu \mathrm{M})$, pertussis toxin (PTX; $0.1 \mathrm{nM})$, dopamine (DA; $1 \mu \mathrm{M})$, PTX $(0.1 \mathrm{nM})$ plus DA $(1 \mu \mathrm{M})$ on intestinal $\mathrm{Na}^{+}, \mathrm{K}^{+}$-ATPase activity in (A) 20- and (B) 60-day old rats. Columns represent means of four to five experiments per group; vertical lines show s.e.mean. *Significantly different from corresponding control values $(P<0.05$; Newman-Keuls test). 
Table 1 Levels of L-DOPA, noradrenaline (NA), dopamine (DA), DOPAC, 3-MT and HVA and DA/NA ratios in the jejunal mucosa of 20 - and 60-day old rats

\begin{tabular}{|c|c|c|c|c|c|c|c|}
\hline & $\begin{array}{c}L-D O P A \\
\left(\mathrm{pmol} / \mathrm{g}^{-1}\right)\end{array}$ & $\begin{array}{c}N A \\
\left(\mathrm{pmol} / \mathrm{g}^{-1}\right)\end{array}$ & $\begin{array}{c}D A \\
\left(\mathrm{pmol} / \mathrm{g}^{-1}\right)\end{array}$ & $\begin{array}{c}D O P A C \\
\left(\mathrm{pmol} / \mathrm{g}^{-1}\right)\end{array}$ & $\begin{array}{c}3-M T \\
\left(\mathrm{pmol} / \mathrm{g}^{-1}\right)\end{array}$ & $\begin{array}{c}H V A \\
\left(\mathrm{pmol} / \mathrm{g}^{-1}\right)\end{array}$ & $\begin{array}{c}D A / N A \\
(\%)\end{array}$ \\
\hline $\begin{array}{l}20 \text {-day old } \\
60 \text {-day old }\end{array}$ & $\begin{array}{l}460 \pm 47 * \\
279+47\end{array}$ & $\begin{array}{l}522 \pm 113^{*} \\
1448+97\end{array}$ & $\begin{array}{c}232 \pm 17 * \\
97+15\end{array}$ & $\begin{array}{l}4 \pm 1 \\
7+1\end{array}$ & $\begin{array}{c}264 \pm 58 * \\
29+3\end{array}$ & $\begin{array}{l}66 \pm 7 * \\
43+2\end{array}$ & $\begin{array}{l}0.60 \pm 0.17^{*} \\
0.08+0.01\end{array}$ \\
\hline
\end{tabular}

Values are mean \pm s.e.mean of five experiments per group. Significantly different from corresponding values in 60 -day old $(* P<0.05)$.

al., 1991; Guimarães et al., 1994; McMillian et al., 1983; Takayanagi et al., 1989). On the other hand, it is interesting to mention that noradrenaline levels in the jejunal wall of 20-day rats were markedly higher (28 fold) than in 60-day old rats, which is in agreement with previous findings (Finkel et al., 1994; Vieira-Coelho et al., 1998). In the present study, the subtype of $\alpha$-adrenoceptor involved in this response of dopamine has not been examined.

Under our experimental conditions an increase in jejunal $I_{s c}$ can be due to a decrease in sodium absorption, a decrease in chloride secretion or both (Vieira-Coelho \& Soares-da-Silva, 1998). The finding that only ouabain, but not furosemide prevented the increase in $\mathrm{I}_{\mathrm{sc}}$ produced by SKF 38393 strongly suggests that the effect of $D_{1}$ receptor activation is a decrease in sodium movement across the jejunal epithelium from the mucosal to the serosal side, most probably as a result of $\mathrm{Na}^{+}, \mathrm{K}^{+}$-ATPase inhibition. This view is reinforced by the observation that both dopamine and the selective $\mathrm{D}_{1}$ agonist, SKF 38393, produced a significant inhibition of the $\mathrm{Na}^{+}, \mathrm{K}^{+}$ATPase activity in isolated jejunal epithelial cells obtained from young rats. It is interesting to note that in adult rats dopamine is devoid of inhibitory effect upon $\mathrm{Na}^{+}, \mathrm{K}^{+}$-ATPase, which fits well the data obtained on rheogenic transport. This failure of dopamine to inhibit jejunal $\mathrm{Na}^{+} \mathrm{K}^{+}$-ATPase activity is most likely not related to the absence of receptors for the amine, since density of binding sites for $\left[{ }^{3} \mathrm{H}\right]-\mathrm{Sch} 23390$ was even slightly greater in adult than in young rats, with similar $\mathrm{K}_{\mathrm{D}}$ 's. On the other hand, jejunal $\mathrm{Na}^{+}, \mathrm{K}^{+}$-ATPase was also found to respond with inhibition to stimuli that are known to be involved in transduction mechanisms set into motion during activation of $\mathrm{D}_{1}$ receptors, such as stimulation of PKA and PKC pathways (Bertorello \& Aperia, 1990b; Hussain \& Lokhandwala, 1998; Jose et al., 1992). In fact, the inhibitory effects of dopamine upon renal $\mathrm{Na}^{+}, \mathrm{K}^{+}$-ATPase activity is accompanied by activation of adenylate cyclase (Bertorello \& Aperia, 1990a) and phospholipase C (Vyas et al., 1992).

Altogether, these results would suggest that jejunal cells from adult rats are endowed with the necessary machinery to respond to dopamine; the cells are endowed with a considerable number of receptors and jejunal $\mathrm{Na}^{+}, \mathrm{K}^{+}$ATPase is an effector protein for PKA and PKC. Thus, this data suggests that abnormal regulation of $\mathrm{Na}^{+}, \mathrm{K}^{+}$-ATPase by dopamine may not arise from a defect in effector mechanisms. Rather, they suggest the defect occurs prior to the effector mechanism, most probably at the level of $G$ proteins. In fact, GTP $\gamma$ S, a nonhydrolyzable analogue of GTP, that irreversibly activates $G$ proteins, decreased in a concentration dependent manner jejunal $\mathrm{Na}^{+}, \mathrm{K}^{+}$-ATPase activity in young but not in adult rats. This view is reinforced by the fact that GDP $\beta S$, an analogue of GTP that does not activate G proteins, had no effect on intestinal $\mathrm{Na}^{+}, \mathrm{K}^{+}$-ATPase in both young and adult animals. Treatment of jejunal cells with CTX also inhibited $\mathrm{Na}^{+}, \mathrm{K}^{+}$-ATPase activity, and it would appear, therefore, that a $G$ protein of the $G_{s}$ class is involved in the inhibitory pathway. Because dopamine inhibits $\mathrm{Na}^{+}, \mathrm{K}^{+}$-ATPase activity, it is suggested the effects of dopamine upon $\mathrm{Na}^{+}, \mathrm{K}^{+}$-
ATPase are mediated via $\mathrm{G}_{\mathrm{s}}$ pathway. Failure of dopamine, GTP $\gamma$ S and CTX to inhibit jejunal $\mathrm{Na}^{+}, \mathrm{K}^{+}$-ATPase activity in adult rats is in agreement with the suggestion that the $\alpha_{\mathrm{s}}$ subunit is subnormal. Because PTX blocks the activation of Gi/o pathways by agonists (Birnbaumer, 1990; Sunyer et al., 1989), and the inhibitory effect of dopamine was not blocked by PTX, it is suggested that inhibition of sodium pump by dopamine is not mediated by $\mathrm{G}$ proteins of the $\mathrm{Gi} / \mathrm{o}$ class. Rather, the results presented here indicate that $\mathrm{Gi} / \mathrm{o}$ proteins may mediate a stimulatory pathway that involves dopamine, since inhibition of jejunal $\mathrm{Na}^{+}, \mathrm{K}^{+}$-ATPase activity by dopamine is potentiated by PTX. These results, combined with the CTX results, suggest that dopamine has a dual stimulatory and inhibitory effect on $\mathrm{Na}^{+}, \mathrm{K}^{+}$-ATPase activity that is mediated by $\mathrm{Gs}$ and $\mathrm{Gi} / \mathrm{o}$ class of $\mathrm{G}$ proteins, respectively. This is particularly evident in young rats, which respond to CTX and dopamine with inhibition of $\mathrm{Na}^{+}, \mathrm{K}^{+}$ATPase activity, the latter effect being potentiated by PTX. To a less extent, this is also true for adult rats. One possible interpretation is that binding of dopamine to its receptor activates both $\mathrm{Gs}$ and $\mathrm{Gi} / \mathrm{o}$; stimulatory $\alpha_{\mathrm{i} / \mathrm{o}}$ pathway is counterbalanced by inhibitory $\alpha_{\mathrm{s}}$ pathway. Net inhibition by dopamine is achieved via an inhibitory $\beta \gamma$ pathway, which is subnormal in adult animals. Alternatively, it might be hypothesized that subnormal activation of $\beta \gamma$ pathway and $\alpha_{\mathrm{s}}$-subunit would result from defective dissociation of the $\alpha$ subunit from the $\beta \gamma$-subunits. The findings presented here, namely those concerning the effects of dopamine, GTP $\gamma \mathrm{S}$, CTX and PTX alone and plus dopamine upon jejunal $\mathrm{Na}^{+}, \mathrm{K}^{+}$-ATPase activity, are quite similar to those observed at the kidney level in spontaneous hypertensive rats (SHR) and their corresponding normotensive controls, the Wistar-Kyoto (WKY) rats (Gurich \& Beach, 1994). Dual activation of G proteins by one ligand/receptor interaction has been described in other systems (Eason et al., 1992; Gurich \& Beach, 1994). At the kidney level, there is evidence that PTX-sensitive G proteins of $\mathrm{Gi} / \mathrm{o}$ class also play a role in dopamine-mediated inhibition of $\mathrm{Na}^{+}, \mathrm{K}^{+}$-ATPase activity, most likely via stimulation of $\mathrm{D}_{2}$-like receptors (Bertorello \& Aperia, 1989; 1990a). This is unlikely to be the case in the rat jejunum, given the fact that dopamine-mediated inhibition of $\mathrm{Na}^{+}, \mathrm{K}^{+}$ATPase activity and increases in $\mathrm{I}_{\mathrm{sc}}$ were insensitive to $\mathrm{S}$ sulpiride, a selective $\mathrm{D}_{2}$ receptor antagonist. Furthermore, the selective $D_{2}$ receptor agonist quinerolane failed to alter $\mathrm{Na}^{+}, \mathrm{K}^{+}$-ATPase activity and $\mathrm{I}_{\mathrm{sc}}$.

Intestinal function is determined by a developmental process that has a great impact in maintaining electrolyte and water metabolism (Younoszai et al., 1978). At this stage of maturation, the possible occurrence of complementary functions between the intestine and the kidney may be essential to achieve adequate electrolyte and water homeostasis. In fact, intestinal $\mathrm{Na}^{+}, \mathrm{K}^{+}$-ATPase activity in young rats was lower than in adult rats, was sensitive to inhibition by dopamine (anti-absorptive) and less sensitive to the $\alpha_{2}$-adrenoceptor stimulation (pro-absorptive) in comparison with that occurring in animals with a mature renal function. All the data 
reported here in young rats demonstrate that the intestine at this age is less absorptive and more susceptive to secretion. This is in agreement with the clinical finding that the major disorder of water and electrolyte metabolism in children is dehydrating diarrhoea, that contributes to higher mortality rates at young ages (Meyers, 1994). Because lack of response to dopamine in adult rats at the intestinal level appears to result from subnormal regulation of $G$ proteins (subnormal activation of $\alpha_{\mathrm{s}}$-subunit, subnormal activation of $\beta \gamma$ pathway or subnormal dissociation of the $\alpha$-subunit from the $\beta \gamma$ subunits) is compatible with a healthy life, in contrast to that occurring at the kidney level in SHR, one should think more on evolutionary or adaptation processes rather than on defective mechanisms.

In conclusion, the data presented here strongly suggest that in young rats, dopamine produce a decrease in jejunal

\section{References}

BERTORELlO, A. \& APERIA, A. (1989). Regulation of $\mathrm{Na}(+)-\mathrm{K}(+)$ ATPase activity in kidney proximal tubules: involvement of GTP binding proteins. Am. J. Physiol., 256, F57-F62.

BERTORELLO, A. \& APERIA, A. (1990a). Inhibition of proximal tubule $\mathrm{Na}(+)-\mathrm{K}(+)$-ATPase activity requires simultaneous activation of DA1 and DA2 receptors. Am. J. Physiol., 259, F924-F928.

BERTORELlO, A. \& APERIA, A. (1990b). Short-term regulation of $\mathrm{Na}+, \mathrm{K}(+)$-ATPase activity by dopamine. Am. J. Hypertens., 3, $51 \mathrm{~S}-54 \mathrm{~S}$.

BINDER, H.J. (1983). Absorption and secretion of water and electrolytes by small and large intestine. In Seisinger, O. \& Fordtran, O. eds. Gastrointestinal Disease. pp. 812-829. Philadelphia: W.B. Saunders.

BIRNBAUMER, L. (1990). G-proteins in signal transduction. Annu. Rev. Pharmacol. Toxicol., 30, 675-705.

DONOWITZ, M., ELTA, G., BATTISTI, L., FOGEL, R. \& LABELSCHWARTZ, E. (1983). Effects of dopamine and bromocriptine on rat ileal and colonic transport. Gastroenterology, 84, 516523.

EAKER, E.Y., BIXLER, G.B., DUNN, A.J., MORESHEAD, W.V. \& MATHIAS, J.R. (1988). Dopamine and norepinephrine in the gastrointestinal tract of mice and the effects of neurotoxins. $J$. Pharmacol. Exp. Ther., 244, 438-442.

EASON, M.G., KUROSE, H., HOLT, B.D., RAYMOND, J.R. \& LIGGETT, S.B. (1992). Simultaneous coupling of alpha2-adrenergic receptors to two G-proteins with opposing effects. J. Biol. Chem., 267, 15795-15801.

ESPLUGUES, J.V., CARAMONA, M.M., MOURA, D. \& SOARES-DASILVA, P. (1985). Effects of chemical sympathectomy on dopamine and noradrenaline content of the dog gastrointestinal tract. J. Auton. Pharmacol., 5, 189-195.

FINKEL, Y., EKLOF, A.C., GRANQUIST, L., SOARES-DA-SILVA, P. \& BERTORELLO, A.M. (1994). Endogenous dopamine modulates jejunal sodium absorption during high-salt diet in young but not in adult rats. Gastroenterology, 107, 675-679.

GIL-MARTIN, E., FERNANDEZ-BRIERA, A. \& CALVO, P. (1997). Effects of chronic ethanol treatment withdrawal on $\left({ }^{3} \mathrm{H}\right) \mathrm{SCH} 23390$ binding to rat strital membranes. Neuropharmacology, 36, $101-106$.

GITLER, M.S., PICCIO, M.M., ROBILLARD, J.E. \& JOSE, P.A. (1991). Characterization of renal alpha-adrenoceptor subtypes in sheep during development. Am. J. Physiol., 260, R407-R412.

GOLDBERG, L.I. \& RAJFER, S.I. (1985). Dopamine receptors: applications in clinical cardiology. Circulation, 72, 245-248.

GUIMARÃES, S., MOURA, D., PAIVA, M.Q. \& VAZ-DA-SILVA, M.J. (1994). Lack of pre- and postjunctional beta adrenoceptormediated effects in the canine saphenous vein at birth. $J$. Pharmacol. Exp. Ther., 268, 990-995.

GURICH, R.W. \& BEACH, R.E. (1994). Abnormal regulation of renal proximal tubule $\mathrm{Na}^{+}-\mathrm{K}^{+}$-ATPase by $\mathrm{G}$ proteins in spontaneous hypertensive rats. Am. J. Physiol., 267, F1069-F1075.

HORIUCHI, A., ALBRECHT, F.E., EISNER, G.M., JOSE, P.A. \& FELDER, R.A. (1992). Renal dopamine receptors and pre- and post-cAMP-mediated $\mathrm{Na}^{+}$transport defect in spontaneously hypertensive rats. Am. J. Physiol., 263, F1105-F1111. electrolyte absorption, in the presence of $\alpha$-adrenoceptor blockade. This effect, most probably due to inhibition of $\mathrm{Na}^{+}, \mathrm{K}^{+}$-ATPase, is likely to be mediated by $\mathrm{D}_{1}$ receptors and is not present in adult rats. Jejunal $\mathrm{Na}^{+}, \mathrm{K}^{+}$ATPase activity in young rats is regulated by both CTX- and PTX-sensitive G proteins, but regulation of the enzyme by CTX-sensitive $\mathrm{G}$ proteins is absent in adult animals. Such difference may explain the failure of dopamine to inhibit intestinal $\mathrm{Na}^{+}, \mathrm{K}^{+}$ATPase activity in adult rats.

Supported by grant SAU/29/95 from Fundação para a Ciência e a Tecnologia.

HUSSAIN, T. \& LOKHANDWALA, M.F. (1998). Renal dopamine receptor function in hypertension. Hypertension, 32, 187-197.

JOSE, P.A., RAYMOND, J.R., BATES, M.D., APERIA, A., FELDER, R.A. \& CAREY, R.M. (1992). The renal dopamine receptors. J. Am. Soc. Nephrol., 2, 1265-1278.

KIMMICH, G.A. (1990). Isolation of intestinal epithelial cells and evaluation of transport functions. Meth. Enzymol., 192, $324-$ 340 .

LIU, L. \& COUPAR, I.M. (1997). Role of alpha2- adrenoceptors in the regulation of intestinal water transport. Br. J. Pharmacol., 120, $892-898$.

MARMON, L.M., ALBRECHT, F., CANESSA, L.M., HOY, G.R. \& JOSE, P.A. (1993). Identification of dopamine $1 \mathrm{~A}$ receptors in the rat small intestine. J. Surg. Res., 54, 616-620.

MCMILliAN, M.K., SCHANBERG, S.M. \& KUHN, C.M. (1983). Ontogeny of rat hepatic adrenoceptors. J. Pharmacol. Exp. Ther., 227, $181-186$.

MEYERS, A. (1994). Fluid and electrolyte therapy for children. Curr. Opin. Pediatr., 6, 303-309.

MOTULSKY, H.J., SPANNARD, P. \& NEUBIG, R. (1994). GraphPad Prism (version 1.0). GraphPad Prism Software Inc.: San Diego, U.S.A.

NELlANS, H.N., FRIZZELL, R.A. \& SCHULTZ, S.G. (1974). Brushborder processes and transepithelial $\mathrm{Na}$ and $\mathrm{Cl}$ transport by rabbit ileum. Am. J. Physiol., 226, 1131-1141.

QUARONI, A., WANDS, R.L., TRESSTAD, K.L. \& ISSELBACHER, K.J. (1979). Epitheliod cell cultures from rat small intestine. J. Cell. Biol., 80, $248-265$.

QUIGLEY, J.P. \& GOTTERER, G.S. (1969). Distribution of Na,Kstimulated ATPase activity in rat intestinal mucosa. Biochim. Biophys. Acta., 173, 456-468.

ROBILlARD, J., SEGAR, J., SMITH, F., GUILLERY, E. \& JOSE, P. (1992). Mechanisms regulating renal sodium excretion during development. Pediatr. Nephrol., 6, 205-213.

SOARES-DA-SILVA, P., PESTANA, M., VIEIRA-COELHO, M.A. FERNANDES, M.H. \& ALBINO-TEIXEIRA, A. (1995). Assessment of renal dopaminergic system activity in the nitric oxide-deprived hypertensive rat model. Br. J. Pharmacol., 114, $1403-1413$.

SUNYER, T., MONASTIRSKY, B., CODINA, J. \& BIRNBAUMER, L. (1989). Studies on nucleotide and receptor regulation of Gi proteins: effects of pertussis toxin. Mol. Endocrinol., 3, 11151124 .

TAKAYANAGI, I., MAEDA, O. \& KOIKE, K. (1989). Effect of aging on presynaptic alpha 2-adrenoceptor mechanisms in guinea pig ileum. Comp. Biochem. Physiol. C, 92, 419-423.

VIEIRA-COELHO, M.A. \& SOARES-DA-SILVA, P. (1993). Dopamine formation, from its immediate precursor 3,4-dihydroxyphenylalanine, along the rat digestive tract. Fund. Clin. Pharmacol., 7, $235-243$.

VIEIRA-COELHO, M.A. \& SOARES-DA-SILVA, P. (1998). Alpha ${ }_{2}$ adrenoceptors mediate the effect of dopamine on adult rat jejunal electrolyte transport. Eur. J. Pharmacol., 356, 59-65.

VIEIRA-COELHO, M.A., GOMES, P., SERRÃO, M.P. \& SOARES-DASILVA, P. (1997). Renal and Intestinal Autocrine Monoaminergic Systems: dopamine versus 5-hydroxytryptamine. Clin. Exp. Hypertens., 19, $43-58$. 
VIEIRA-COELHO, M.A., LUCAS TEIXEIRA, V.A., FINKEL, Y., SOARES-DA-SILVA, P. \& BERTORELLO, A.M. (1998). Dopamine dependent inhibition of jejunal $\mathrm{Na}^{+}, \mathrm{K}^{+}$-ATPase during highsalt diet in young but not in adult rats. Am. J. Physiol., 275, $1317-1323$.

VYAS, S.J., EICHBERG, J. \& LOKHANDWALA, M.F. (1992) Characterization of receptors involved in dopamine-induced activation of phospholipase-C in rat renal cortex. J. Pharmacol. Exp. Ther., 260, $134-139$.
YOUNOSZAI, M.K., SAPARIO, R.S. \& LAUGHLIN, M. (1978). Maturation of jejunum and ileum in rats. J. Clin. Invest., 68 , $271-280$

(Received August 4, 1999 Revised October 15, 1999 Accepted October 27, 1999) 